\title{
СИЛИ ТА ЗАСОБИ ЗАБЕЗПЕЧЕННЯ НАЦІОНАЛЬНОÏ БЕЗПЕКИ УКРАЇНИ
}

Талалай Д. В., Щербина Л. І.

\begin{abstract}
У статті визначено основні детермінанти, які зумовлюють потребу розвитку й удосконалення механізмів забезпечення національної безпеки України. На підставі юридичного аналізу визначено коло суб'єктів забезпечення національної безпеки, їхній правовий статус, що дало змогу з'ясувати сили та засоби ії забезпечення. Сформульовано авторський підхід до співвідношення категорій «суб'єкт національної безпеки» й «суб'єкт забезпечення начіональної безпеки». Окреслено правову основу функціонування та механізми координації їхньої діяльності.
\end{abstract}

Ключові слова: національна безпека, суб'єкт, сили, засоби, система.

B cтатье определены главные детерминанты, которые обуславливают необходимость развития и усовершенствования механизмов обеспечения национальной безопасности Украины. На основе юридического анализа определён круг субъектов обеспечения национальной безопасности, их правовой статус, что позволило выяснить силы и средства ее обеспечения. Сформулировано авторский подход $\kappa$ соотношению категорий «субъект национальной безопасности» и «субъект обеспечения национальной безопасно сти». Очерчена правовая основа функционирования и механизмы координации их деятельности.

Ключевые слова: национальная безопасность, субъект, силы, средства, система.

The research article gives the outlook about main reasons for enhancing and development the mechanisms of providing the national security of Ukraine. Moreover, it is being determined subjects which ensure national security due to legal analyzes, their legal status, that helped to clarify assets for it's maintenance. Summed up the original approach for correlation between such terms as subjects of national security and subjects which ensure national security. Lined up legal framework of their activity and arrangements for coordination their activity.

An authors summarize that there are challenging issues about resource and manpower of providing the national security of Ukraine, cooperation and coordination during the peacetime and the crises period.

Furthermore, it is said that the new act of legislation "About the national security of Ukraine" became as comprehensive law that system of providing the national security rules strictly with. What is more, this legislative act stipulates the list of subjects which ensure the national security. It is being mentioned that it is a good practice to frame the list of subjects in a legislative act due to approach setting the special system of state bodies as much as getting complex rules in such specific affairs.

There is a conclusion about approach of getting understating main functional orientation and structure of the subjects ' legal status and competence. In addition, authors underlined that such subjects refer to state apparatus, have their own competition, structure, location of authority, special procedure of setting-up, use special forms and approaches of activity, ac under the authority of state.

Талалай Д. В., Щербина Л. І., 2019
It is defined that category "subject of providing the national security" involve separate term "subject of providing the national security". They are being deferred with an ambit of authority and it 's sort as well on a few groups.

As a main conclusion it is said that sectorial and cross-sectorial authorized bodies have to be used for the defense national interests of the state. Their coordination has to be made within special systems of administration.

Key words: national security, subject, assets, system.

Постановка проблеми та їі актуальність. Аналіз кризових явищ у політичній, воєнній, економічній, соціальній та інших сферах суспільного життя свідчить про нагальність потреби в більш ретельному підході до розвитку й удосконалення механізмів забезпечення національної безпеки України.

Протягом останніх років досить велику небезпеку для України становлять такі чинники, як посягання на їі державний суверенітеті територіальну цілісність, втручання у внутрішні справи країни з боку інших держав, економічна нестабільність, які призводять до значних деструктивних наслідків соціально-політичного характеру.

Основу чинних механізмів реагування на такі загрози становлять вітчизняні, передусім військові, формування, правоохоронні органи, державні органи спеціального призначення з правоохоронними функціями, а також інші уповноважені суб'єкти, у розпорядженні яких наявні відповідні засоби саме для адекватної протидії впливу вищевказаних негативних факторів.

Відмінності у правовому статусі, їхня компетенція та специфіка діяльності кожного із суб'єктів зумовлюють потребу пошуку й обґрунтування ефективних шляхів удосконалення управлінського, нормативно-правового, теоретико-методологічного, науково-технічного та іншого супроводження організації взаємодії, координації та комплексного застосування наявних сил і засобів під час виконання покладених на них завдань у мирний час і в особливий період.

Така позиція зумовлена насамперед існуванням певних прикладних наукових досліджень у сфері розроблення теорії забезпечення національної безпеки, у тому числі державної та воєнної безпеки, з питань удосконалення профілактичних, охоронних, режимних, обмежувальних заходів і використання специфічних методів у діяльності уповноваженими суб'єктами, а також у контексті реформування сектору безпеки і оборони України.

Однак досить тривалий i, на жаль, досі незавершений характер реформування окремих компетентних державних органів, насамперед правоохоронних органів і військових формувань, утворення нових структур, неоднозначність підходів до визначення сил забезпечення національної безпеки України, а також недостатній рівень задоволення вимог практики наявним нау- 
ковим доробком з вищевказаних питань через призму нормативно-правового забезпечення створюють певні труднощі для вдосконалення й розвитку, що насамперед ускладнює захист національних інтересів держави.

Аналіз останніх досліджень і публікацій. Фундаментальні питання нормативно-правових засад функціонування системи забезпечення національної безпеки в наукових працях розглядали такі вчені: В.Ю. Богданович, І.О. Кириченко, В.О. Косевцов, О.Г. Комісаров, В.В. Крутов, С.С. Кудінов, С.О. Кузніченко, Н.Р. Нижник, В.Г. Новицький, І.І. Мусієнко, В.Г. Пилипчук, І.М. Рижов, Б.Л. Розвадовський, Г.П. Ситник, О.П. Снігерьов, І.В. Слюсарчук, М.П. Стрельбицький, M.О. Шилін і багато інших. Утім, незважаючи на наявність низки досліджень, у т. ч. й тих, що мають міждисциплінарний характер, у яких з'ясовано окремі питання у сфері забезпечення національної безпеки України, у т. ч. державної та воєнної безпеки, недостатньо вивченими лишаються питання визначення сил і засобів iї забезпечення, взаємодії та координації їхньої діяльності в мирний час і в особливий період, з огляду на те що розроблення цієї проблематики не втрачає своєї актуальності та $є$ своєчасним.

Метою статті $\epsilon$ визначення кола суб'єктів забезпечення національної безпеки, їхнього правового статусу, а також з'ясування сил і засобів забезпечення національної безпеки держави та правової основи їхньої діяльності.

Виклад основного матеріалу. Національна безпека забезпечується всіма наявними в розпорядженні держави засобами. Із загальних положень теорії держави та права відомо, що вона забезпечується насамперед завдяки реалізації вітчизняної політики в усіх сферах суспільних відносин, а також системи заходів економічного, політичного й воєнного характеру, адекватних рівню загроз життєво важливим інтересам людини, суспільства та держави. Саме держава покликана бути основним суб'єктом їі забезпечення, яка здійснює своїх функції в цій сфері через органи законодавчої, виконавчої та судової гілок влади.

Для забезпечення сприятливих умов існування й розвитку народу України, збереження та примноження його матеріальних і духовних цінностей у державі системно розробляється й удосконалюється сукупність правових норм, що регулює суспільні відносини у сфері національної безпеки, нормативні положення яких забезпечують збалансованість і визначеність компетенції органів державної влади й управління, формування й розвиток уповноважених суб'єктів забезпечення національної безпеки, а також механізмів контролю й нагляду за їхньою діяльністю. Більше того, зазначене законодавство в сукупності закріплює єдину систему цінностей, цілей, завдань і заходів у цій сфері, а також визначає орієнтовний перелік загроз. Така сукупність нормативно-правових актів $є$ своєрідним системоутворювальним «дороговказом» у сфері забезпечення національної безпеки та включає нормативно-правові акти - від доктрини національної безпеки до планів дій суб'єктів забезпечення національної безпеки в конкретних умовах конкретного періоду [1, с. 268-269].

Саме таким системоутворювальним нормативно-правовим актом став новий Закон України «Про національну безпеку України», згідно з положеннями якого формується державна система забезпечення націо- нальної безпеки. Загальні риси системоутворювального законодавства нині визначені в розділі V «Планування у сферах національної безпеки і оборони» [2], де передбачено розроблення стратегій, концепцій, програм, планів розвитку органів безпеки і оборони, управління ресурсами й ефективного їх розподілу, якими забезпечується планування та реалізація державної політики в цих сферах (ст. 25). Саме цим нормативно-правовим актом безпосередньо визначаються та розмежовуються повноваження державних органів у сферах національної безпеки і оборони, створюється основа для інтеграції політики та процедур органів державної влади, інших державних органів, функції яких стосуються національної безпеки і оборони, сил безпеки й оборони, визначається система командування, контролю та координації операцій сил безпеки і оборони, запроваджується всеосяжний підхід до планування у сферах національної безпеки і оборони, забезпечуючи в такий спосіб демократичний цивільний контроль над органами й формуваннями сектору безпеки і оборони.

Виходячи зі змісту цього Закону, саме сектор безпеки і оборони відіграє досить важливу роль у забезпеченні безпеки людини, суспільства та держави від загроз. Законодавець визначає цю категорію як «систему органів державної влади, Збройних Сил України, інших утворених відповідно до законів України військових формувань, правоохоронних та розвідувальних органів, державних органів спеціального призначення з правоохоронними функціями, сил цивільного захисту, оборонно-промислового комплексу України, діяльність яких перебуває під демократичним цивільним контролем і відповідно до Конституції за законів України за функціональним призначенням спрямована на захист національних інтересів від загроз» (п. 16 ст. 1).

3 огляду на це, варто погодитися з думкою вчених, що цілком правильною практикою $\epsilon$ визначення суб'єктів забезпечення національної безпеки, основних напрямів їхньої діяльності та взаємодії саме на рівні норм-принципів, з огляду на те що це в сукупності утворює систему забезпечення національної безпеки та основу, вихідні принципи (задум), які визначають стратегію діяльності визначеного кола суб'єктного складу або стратегію забезпечення національної безпеки [3, с. 280].

Визначення кола уповноважених суб'єктів на нормативно-правовому рівні передбачає перерахування ознак і якостей, які мають бути притаманні суб'єкту, щоб він міг виступати в ролі адресата норм певної галузі законодавства [3, с. 289]. 3 огляду на це, ми підтримаємо наукову думку, що така сукупність установлених нормами права якостей, які дають суб'єкту можливість бути носієм юридичних прав та обов'язків у тій чи іншій сфері суспільних відносин, називається правосуб'єктністю, яка може бути загальною, галузевою та спеціальною, останні дві з яких і $\epsilon$ характерними ознаками суб'єктів забезпечення національної безпеки.

Із загальної теорії права відомо, що будь-яка характеристика суб'єкта охоплюється поняттям «правовий статус», а також і те, що досить велика кількість учених-юристів розглядає правовий статус як складне явище, яке об'єднує не тільки права, обов'язки, відповідальність, а й інші елементи - принципи діяльності, правоздатність, гарантії законності тощо $[4$, с. $61 ; 5$, с. 123$]$. 
У цьому контексті варто підтримати думку вченого-адміністративіста Б.Н. Лазарева, що визначення поняття правового статусу суб'єкта можна вивести, відповівши на питання: до якого виду органів за основним змістом діяльності він належить, хто його засновує, утворює, хто формує його керівний склад; кому орган підпорядкований, підзвітний, підконтрольний і перед ким відповідальний; яка його компетенція; хто йому підзвітний і підконтрольний, чиї акти він може скасовувати самостійно, змінювати, припиняти, опротестовувати; яка юридична сила актів цього органу, яке його офіційне найменування; якими державними символами орган має право користуватися; які джерела його фінансування; чи має орган права юридичної особи [6, с. 248-249].

Тому, на наш погляд, усі наявні підходи об'єднує те, що незаперечними складниками правового статусу будь-якого державного органу $є$ права, обов'язки, гарантії законності діяльності та юридична відповідальність. Саме такий підхід дає змогу з'ясувати головну функціональну спрямованість і структуру правового статусу суб'єктів забезпечення національної безпеки.

Сукупність нормативно-правових актів, яка безпосередньо нормативно визначає компетенції окремих органів державної влад, тобто сукупності прав та обов'язків, що надаються їм для виконання функцій із забезпечення національної безпеки, у теорії вітчизняної правової науки називають правосуб'єктним законодавством [3, с. 291-292].

Так, зокрема, на нашу думку, до його переліку будуть належати закони України, якими визначено правовий статус та організаційно-правові засади діяльності окремих суб'єктів, які, згідно з чинним Законом України «Про національну безпеку України», включені до Сектору безпеки і оборони.

Більше того, цілісний ряд функцій системи забезпечення національної безпеки $є$ досить різноманітним і включає не лише ті з них, котрі визначені в Законі України «Про національну безпеку України» та окремих законодавчих актах, які визначають статус окремих суб'єктів у цій сфері, а й планування діяльності органів, сил і засобів безпеки в різних режимах функціонування системи, організацію взаємодії між різними суб'єктами національної безпеки, координацію діяльності органів і сил у ході проведення заходів із забезпечення безпеки та оборони.

Отже, аналіз нормативно-правових актів, які визначають правовий статус суб'єктів забезпечення національної безпеки, підтверджує наукові тези, що вони $\epsilon$ частиною державного апарату, мають компетенцію, структуру, територіальний масштаб діяльності, утворюються в порядку, установленому законами або іншими нормативно-правовими актами, застосовують визначені форми та методи діяльності, наділені правом виступати від імені держави й покликані в порядку законодавчої, судової, виконавчої й розпорядницької діяльності здійснювати повсякденне забезпечення національної безпеки України. Правоздатність і дієздатність суб'єктів забезпечення національної безпеки виникає водночас із їхнім утворенням і визначенням компетенції, а припиняється у зв'язку з ліквідацією чи скасуванням [3, с. 294].

Основні функціональні обов'язки в чинній системі забезпечення національної безпеки України, згідно з Конституцією України, виконують Президент України;
Верховна Рада України; Кабінет Міністрів України; Рада національної безпеки і оборони України; міністерства й інші центральні органи виконавчої влади; місцеві державні адміністрації й органи місцевого самоврядування; сектор безпеки і оборони України; політичні та громадські інститути.

Разом із тим з наукового та практичного поглядів необхідним $\epsilon$ безпосереднє визначення сил і засобів забезпечення національної безпеки. Така потреба продиктована тим, що досить важливим є розуміння того, яке коло суб'єктів, якими $\epsilon$ їхня компетенція та можливості, а також які засоби безпосередньо можуть бути застосовані в межах чинного законодавства, які завдання з реалізації національних інтересів у тій чи іншій безпековій сфері держави.

На нашу думку, вищевказані категорії за змістом збігаються з таким поняттям, як «суб'єкт забезпечення національної безпеки", розкривши зміст якого можна конкретизувати й окреслити коло наявних сил і засобів, що можуть бути задіяні для захисту національних інтересів від загроз як у мирний час, так і в особливий період.

У цьому контексті зазначимо, що в силу специфіки суспільних відносин насамперед владного характеру, що виникають у ході діяльність системи державних органів, у т. ч. правоохоронних органів і військових формувань, вони становлять предмет правового регулювання саме адміністративного права. 3 огляду на це, убачаємо за можливе дати визначення вищевказаної категорії, взявши за основу поняття «суб'єкт адміністративного права».

У працях окремі проблемні питання суб'єктів адміністративного права розглядали такі вчені, як В.Б. Авер'янов, Г.В. Атаманчук, К.К. Афанасьєв, О.М. Бандурка, Д.М. Бахрах, В.М. С.Т. Гончарук, І.С. Гриценко, А.І. Єлістратов, О.Ф. Євтихієв, Д.М. Лук'янець, О.Є. Луньов, П.С. Лютіков, С.В. Ківалов, Т.О. Коломоєць, В.Л. Кобалевський, Л.В. Коваль, Ю.О. Тихомиров та інші. Утім, віддаючи належне здобуткам учених у дослідженні проблем суб'єктів адміністративного права, варто зазначити, що в науці українського адміністративного права зазначена проблематика не вичерпується наявним науковим доробком.

У теорії адміністративного права під суб'єктом адміністративного права розуміють фізичних і юридичних осіб, які наділені певним обсягом прав та обов'язків у сфері адміністративно-правового регулювання управлінських відносин і реалізують функції виконавчої влади [7, с. 49-51]. Дещо інакше окремі вчені-адміністративісти, розвиваючи наявні наукові підходи, визначають цю категорію, зокрема, як носія (власника) прав та обов' язків у сфері державного управління, які передбачені адміністративно-правовими нормами, здатного реалізовувати надані права й виконувати покладені обов'язки [8, с. $96 ; 9$, с. 69].

Тому, виходячи з усталених підходів теорії адміністративного права, уважаємо, що категорія «суб'єкт забезпечення національної безпеки» охоплюватиме фізичних осіб і юридичних осіб публічного права, які наділені правами й обов'язками у сфері адміністративно-правового регулювання управлінських відносин, що виникають під час забезпечення національної безпеки, і які реалізують функції виконавчої влади із забезпечення процесу управління загрозами та небезпеками, за якого державними й недержавними інституціями 


\section{Проблеми становлення правової \\ демократичної держави}

гарантується прогресивний розвиток національних інтересів, збереження цінностей, джерел духовного та внутрішнього добробуту народу України, ефективне функціонування самої системи забезпечення національної безпеки держави.

Необхідно враховувати також і те, що категорія «суб'єкт забезпечення національної безпеки» охоплюється поняттям “суб'єкт національної безпеки". Щоб 3'ясувати їх співвідношення, зазначимо, що залежно від обсягу й характеру компетенції, закріплених у правосуб'єктному законодавстві, уся сукупність суб'єктів національної безпеки умовно може бути поділена на:

- суб'єктів загальної компетенції, які здійснюють керівництво всіма чи більшістю напрямів забезпечення національної безпеки (Президент України, Верховна Рада України, Кабінет Міністрів України, Конституційний Суд України, суди загальної юрисдикції, Рада національної безпеки і оборони України, місцеві державні адміністрації та органи місцевого самоврядування);

- суб'єкти галузевої компетенції, які здійснюють керівництво окремими напрямами забезпечення національної безпеки (галузеві міністерства й інші галузеві центральні органи виконавчої влади, Національний банк України, Збройні Сили України, Державна прикордонна служба України й інші військові формування, утворені відповідно до законів України);

- органи міжгалузевої компетенції, які здійснюють міжгалузеве регулювання, міжгалузеву координацію, контрольно-наглядові функції (Генеральна прокуратура України, правоохоронні органи, державні органи спеціального призначення з правоохоронними функціями тощо) [3, с. 295].

На законодавчому рівні коло уповноважених суб'єктів у сфері забезпечення національної безпеки визначається категорією «Сектор безпеки і оборони України», який складається з чотирьох взаємопов'язаних складників: сил безпеки; сил оборони; оборонно-промислового комплексу; громадян і громадських об'єднань, які добровільно беруть участь у забезпеченні національної безпеки (ст. 12) [2].

Варто зазначити, норми про розмежування сил безпеки та оборони стали новелою для вітчизняного законодавства. Законодавець з метою визначення й розмежування повноважень уповноважених суб'єктів, контролю та координації їхніх дій закріпив, що «сили безпеки» правоохоронні та розвідувальні органи, державні органи спеціального призначення з правоохоронними функціями, сили цивільного захисту й інші органи, на які Конституцією та законами України покладено функції із забезпечення національної безпеки України (п. 17 ст. 1); «сили оборони» - Збройні Сили України, а також інші утворені відповідно до законів України військові формування, правоохоронні та розвідувальні органи, органи спеціального призначення з правоохоронними функціями, на які Конституцією та законами України покладено функції із забезпечення оборони держави (п. 18 ст. 1) [2]

Проведений юридичний аналіз також дає можливість зазначити, що хоча громадяни та громадські об'єднання зараховані до кола суб'єктів національної безпеки, проте відповідні положення мають декларативний характер, з огляду на те що законодавча регламентація їхніх прав та обов'язків нині $\epsilon$ незавершеною, потребує ретельного опрацювання та закріплення на законодавчому рівні.
Разом із тим аналіз правосуб'єктного законодавства і практики забезпечення національної безпеки свідчить, що в інституціональній структурі суб'єктів забезпечення національної безпеки має бути чітко визначене ї коло. Насамперед це потрібно для створення ефективної системи управління сектором безпеки і оборони як цілісної функціональної системи, об'єднання оперативних спроможностей конкретних іï складників, постійного підтримання визначених сил у готовності до виконання завдань за призначенням, а також забезпечення планомірного вдосконалення діяльності.

Однак на вершині цього всього стоїть безпосереднє забезпечення безпеки населення держави, а це означає, що конкретизація компетенції та відповідальності на різних рівнях $\epsilon$ належним підґрунтям для ефективної діяльності всієї системи й забезпечення реалізації державної політики в цій сфері.

3 огляду на викладене, можна дійти висновку, що

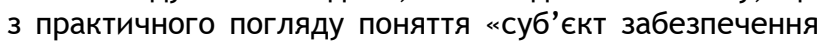
національної безпеки» умовно варто відрізняти від такої категорії, як «суб' єкт національної безпеки», що $\epsilon$ ширшим і включає в себе всю сукупність державних органів влади.

Уважаємо, що до суб'єктів забезпечення національної безпеки варто зарахувати органи галузевої та міжгалузевої компетенції, у тому числі й ті, які на законодавчому рівні визначені як сили безпеки та оборони, адже реалізація саме їхньої компетенції лежить в основі безпосереднього реагування наявними силами й засобами на ті виклики та загрози, що стоять сьогодні перед державою.

Разом із тим зазначимо, що такий підхід $\epsilon$ умовним і не виключає розширення окресленого кола суб'єктів, наприклад, за рахунок громадян і громадських об'єднань, які добровільно беруть участь у забезпеченні національної безпеки, адже захист національних інтересів - це справа всього українського народу та держави загалом.

Між тим сама наявність структур забезпечення національної безпеки та визначення їхнього правового статусу не вирішує всіх проблем у цій сфері. Поточні й перспективні проблеми у сфері забезпечення національної безпеки можуть бути вирішені лише за умови ефективної діяльності уповноважених суб'єктів у рамках єдиної нормативно закріпленої системи. Це, у свою чергу, передбачає необхідність вироблення відповідного механізму координації діяльності не тільки окремих суб'єктів забезпечення національної безпеки, а й ефективного виконання ними взаємозалежних завдань.

Саме тому положеннями Закону України «Про національну безпеки України» спеціальних суб'єктів об'єднано в певну систему, що здатна виконувати зазначені функції, і визначено їх через категорію Сектор безпеки і оборони України. У теорії адміністративного права ï називають «системи надвідомчого міжгалузевими управління».

Сутність такого управління полягає у визначенні основних напрямів соціальної політики держави, розробленні цільових, комплексних та інших державних i регіональних програм розвитку конкретної галузі управління; об'єднанні й координації галузевих систем управління в реалізації міжгалузевих програм і завдань державного управління в цій сфері; забезпеченні організаційної єдності функціонування галузевих систем 
управління; реалізації програм і завдань, що виходять за межі тієї або іншої галузі державного управління, а також вирішенні питань, що мають загальнодержавне, міжрегіональне й регіональне значення [10, с. 344-345].

Успішне виконання завдань щодо забезпечення національної безпеки України багато в чому залежить від організації та здійснення міжгалузевого управління. Вітчизняний науковець С.О. Кузінченко цілком слушно зараховує до таких систем, по-перше, із запобігання й реагування на надзвичайні ситуації воєнного характеру; по-друге, із запобігання й реагування на надзвичайні ситуації соціально-політичного характеру (включаючи надзвичайні ситуації кримінального та некримінального характеру); по-третє, із запобігання й реагування на надзвичайні ситуації техногенного та природного характеру [11, с. 308].

Як уже зазначалося раніше, кожна з указаних систем має власну законодавчу базу, яка становить правове забезпечення й утворює правові режими, у тому числі й особливі правові режими, функціонування відповідної системи.

В Україні з 2014 року органами державної влади з метою адекватного реагування на загрозу застосування воєнної сили проти держави, ліквідації надзвичайних ситуацій соціально-політичного та воєнного характеру вжиті системні заходи щодо запобігання та протидії загрозам життєво важливим інтересам України.

Так, зокрема, Президентом України, Верховною Радою України, Кабінетом Міністрів України, Радою національної безпеки і оборони України реалізовано цілу низку законодавчих ініціатив щодо зміцнення національної безпеки, подолання терористичної загрози, збереження територіальної цілісності, забезпечення безпеки та нормалізації життєдіяльності населення в районі проведення антитерористичної операції, а в подальшому районі проведення Операції об'єднаних сил, підвищення готовності щодо відвернення й нейтралізації загроз національній безпеці держави. Як наслідок, по-перше, розширено перелік завдань Сектору безпеки і оборони, конкретизовано спільні завдання для сил, які беруть участь в АTO та ООС, зокрема для Збройних Сил України, Служби безпеки України, Державної прикордонної служба України, Національної гвардії України тощо; по-друге, чітко визначені завдання, які вони мають виконувати; по-третє, організовано та проведено кризове стратегічне планування застосування Збройних Сил України із залученням інших військових формувань i правоохоронних органів; по-четверте, розроблено Стратегічний замисел застосування Збройних Сил України з відсічі збройної агресії, який став основним документом $з$ питань діяльності військ (сил) в особливий період; по-п'яте, забезпечено ведення в рамках АТО та ООС бойових (спеціальних) операцій силами й засобами Збройних Сил України із залученням інших військових формувань і правоохоронних органів тощо.

Законодавчо визначений і вдосконалений інструментарій відповідних заходів забезпечив досить високу можливість вирішення ширшого переліку завдань за рахунок системи заходів, характерних, як правило, для умов надзвичайних правових режимів, здійснюваних у взаємодії суб'єктами сектору безпеки та оборони України. Система відповідних заходів, як вимога часу, покликана забезпечити адекватне реагування на сучасні прояви загроз національним інтересам держави.
Разом із тим уважаємо, що відповідне законодавство має розроблятися не лише для надання правового поля діяльності окремим суб'єктам на державному рівні, а й забезпечити розроблення ефективних засобів і гнучких механізмів реалізації окремих заходів, у тому числі й тих, що притаманні для надзвичайних правових режимів, у разі виникнення надзвичайних ситуацій загальнодержавного рівня, для відвернення загроз і забезпечення державної безпеки.

Крім виконання загальних завдань, що указані вище, суб'єкти забезпечення національної безпеки забезпечують виконання завдань залежно від напряму діяльності. Ми не будемо зупинятися на завданнях кожного із цих суб'єктів, тому що зазначене визначено чинним законодавством держави, але на підставі проведеного аналізу зазначимо, що сьогодні діяльність визначеного кола суб'єктів здійснюється, як правило, в умовах функціонування, притаманних для особливих правових режимів, однак без фактичного їх уведення.

Правовим підґрунтям для цього $є$ законодавство, яке фактично не зобов'язує, а лише надає право уповноваженим вищим органам державної влади на введення особливих правових режимів. Водночас, як зазначалося вище, держава зобов'язана захищати національної інтереси. За наявності надзвичайних ситуацій загальнодержавного рівня (техногенного характеру, природного, соціального та воєнного), які фактично $є$ підставами для введення в установленому законом порядку, функціонування уповноваженого кола суб'єктів передбачає реалізацію завдань суб'єктів забезпечення національної безпеки і оборони України за такими напрямами: усунення загроз і ліквідація наслідків надзвичайних ситуацій (у т. ч. боротьба з тероризмом, запобігання фінансуванню тероризму, протидія використанню з терористичною метою засобів масового ураження, ліквідація масових заворушень), здійснення заходів правового режиму надзвичайного та воєнного стану.

Висновки. Отже, проблематика сил і засобів забезпечення національної безпеки України лежить у площині нормативно-правових засад функціонування системи ії забезпечення, діяльності уповноважених суб'єктів у цій сфері, їх взаємодії, а також можливостей координації виконання спільних і взаємозалежних завдань на відомчому, міжвідомчому та надвідомчому рівнях як у мирний час, так і в особливий період.

Для захисту національних інтересів від загроз насамперед мають бути задіяні органи галузевої та міжгалузевої компетенції, у тому числі й ті, які на законодавчому рівні визначені як сили безпеки та оборони, які в межах компетенції виконують завдання з безпосереднього реагування на загрози загальнодержавного рівня.

У разі виникнення надзвичайних ситуацій або наявності загроз загальнодержавного рівня координація діяльності уповноважених суб'єктів здійснюється в межах відповідних систем надвідомчого міжгалузевого управління, правову основу діяльності яких утворюють законодавчі акти, якими визначено як правовий статус та організаційно-правові засади діяльності окремих суб'єктів, так й особливості їхньої діяльності в особливих умовах, підзаконні нормативні акти, якими створено відповідні державні системи реагування, відомчі й міжвідомчі накази та інструкції, а також ті нормативно-правові акти, які забезпечують правові режими в державі. 


\section{Проблеми становлення правової демократичної держави}

Разом із тим від рівня теоретичного осмислення й нормативно-правового забезпечення відповідних функціональних систем з урахуванням наявних можливостей наукового супроводження залежить вирішення організаційних питань діяльності суб'єктів забезпечення національної безпеки держави як у мирний час, так і в особливий період.

\section{Література}

1. Теоретико-правові основи забезпечення національної безпеки України : монографія. Київ : Інтертехнологія, 2008. 496 c.

2. Про національну безпеку України : Закон України від 21.06.2018 № 2469-VIII. Урядовий кур'єр. 2018. № 132.

3. Теоретико-правові основи забезпечення національної безпеки України : монографія. Київ : Інтертехнологія, 2008. 496 c.

4. Витрук Н.В. Основы теории правового положения личности в социалистическом обществе. Москва : Наука, 1979. 229 с.

5. Воеводин Л.Д. Юридический статус личности в России : учебное пособие. Москва : Изд-во Моск. ун-та, Норма, Инфра-М, 1997. 304 с.

6. Лазарев Б.М. Государственное управление на этапе перестройки. Москва : Юрид. лит., 1988. 318 с.

7. Адміністративне право. Загальна частина : навчальний посібник. Київ : Центр учбової літератури, 2011. 216 с.
8. Колпаков В.К. Адміністративне право України : підручник. Київ : Юрінком Інтер, 1999. 736 с.

9. Административное право Украины : учебник / под общей ред. С.В. Кивалова. Харков : Одиссей, 2004. 880 с.

10. Кузніченко С.О. Надзвичайні адміністративно-правові режими: зарубіжний досвід та українська модель : монографія. Сімферополь : КРП «Вид-во «Кримнавчпеддержвидав», 2009. 500 с.

11. Кузніченко С.О. Становлення та розвиток інституту надзвичайних адміністративно-правових режимів в України : дис. ... докт. юрид. наук : 12.00.07 / МВС України, Кримськ. юрид. ін-т ОДУВС. Сімферополь, 2010. 463 с.

Талалай Д. В., доктор юридичних наук, доцент, начальник наукової лабораторії № 1 науково-організаційного центру Національної академії Служби безпеки України

Щербина Л. І., кандидат юридичних наук, старший науковий співробітник, головний науковий співробітник наукової лабораторії № 1 науково-організаційного центру Національної академії Служби безпеки України 